\title{
BERNARDINO DE RIBERA'S COMPOSITIONAL SUMMARY: TOLEDO POLYPHONIC CODEX NUMBER 6
}

\section{Carlos Gutiérrez Cajaraville ${ }^{1}$}

\section{English Abstract}

Bernardino de Ribera (ca. 1520 - 1580) was a highly recognized maestro de capilla in the sixteenth century Spain. Nevertheless, his actual status is highly associated with the great figure of Tomás Luis de Victoria, since it seems that both coincided in their years spent at Ávila, Ribera as a consolidated master, Victoria as a young choirboy. The present study analyses the large choirbook that Ribera himself charged as a present for the cathedral of Toledo. The article examines the history of the manuscript (mutilated some years after its making because of the value of its illuminations), the construction of the Codex and the repertoire contained within, showing the importance of some neglected figures like Bernardino, a significant composer that deserves more consideration by himself.

\footnotetext{
${ }^{1}$ At the time of writing the article, Carlos Gutiérrez is a professor of "Musical Critique: History, Theory and Practice" at University of Valladolid. He is also a PhD candidate in his first stages, working on the motet in Spain ca. 1550 - ca. 1580, analyzing its processes of composition, transmission and reception.
} 


\section{Introduction}

Until now, many scholars have set their focus on the sixteenth century Spanish music and, certainly, the advances made over the years are commendable and praiseworthy. However, there is still a long way to go. The richness of the Spanish music of that period is so great that along the way have been great "forgotten" (or, at least, so partially known) masters, somehow obscured by the canonical great figures of Cristóbal de Morales, Francisco Guerrero and, of course, Tomás Luis de Victoria. This is the case of my subject of study, Bernardino de Ribera, who was maestro de capilla in Ávila (1559 - 1562), Toledo (1562 - 1570) and Murcia (1571 - 1580) cathedrals.

In what follows, I provide an in-depth study of the Toledo Polyphonic Codex $\mathrm{N}^{\circ}$ 6 , which contains almost all of the known compositions by Bernardino de Ribera. The proximity and accessibility of the primary sources have largely facilitated my investigation, which I hope could offer some interesting information about broader issues.

\section{State of the Question}

If, as Michael Noone has said, "the manuscript codices of the Cathedral of Toledo are the largest existing source of Renaissance music in Spain", 2 the Polyphonic Codex Number 6 is, without a doubt, one of its greatest jewels. Nonetheless, the manuscript has received relatively little scholarly attention (certainly, less than other Toledo choirbooks), perhaps because it contains works by a single composer whose fame has not matched other Spanish composers of the era.

However, the codex is cited in one of the most noteworthy early Spanish musicological publications, the monumental collection of Spanish sacred music Lira Sacro Hispana, edited by Hilarión Eslava, who proclaimed Bernardino de Ribera as "one of the best masters of the first half of the century" 3 and mentioned a "beautiful, luxurious book" extant in Toledo cathedral. ${ }^{4}$

\footnotetext{
${ }^{2}$ Michael Noone, "La compilación del Códice polifónico toledano, ToleBc16”, Revista de Musicología 16/5 (1993), 2741: “... los códices manuscritos de la Catedral Primada de Toledo, son también la mayor fuente existente de música renacentista en España."

${ }^{3}$ Unless otherwise indicated, translations are my own.

${ }^{4}$ Miguel Hilarión Eslava, Lira Sacro-Hispana: gran colección de obras de música religiosa compuesta por los más acreditados maestro españoles, tanto antiguos como modernos. (Madrid: M. Martín Salazar, 1852 - 1860). Complete quotation reads as follows: ' $\mathrm{D}$ ' Bernardino Ribera de quien no se sabe con seguridad donde fué [sic] maestro, se cree lo fuese en la catedral de Toledo; porque en ella existen
} 
The earliest publication to describe the Toledo Polyphonic Codex $\mathrm{N}^{\mathrm{o}} 6$, written by Felipe Rubio Piqueras, dates from 1925 and consists of a short descriptive inventory of the contents of the manuscript. ${ }^{5}$ Another publication to include a brief account of the codex is Robert Stevenson's classic article, published forty-three years ago in this journal, in which he described the choirbook as "one of the most stunning visually in the entire Toledo polyphonic corpus". 6

Many years later, François Reynaud's study on Toledo polyphony devoted some pages to composers and manuscripts of sacred polyphony present in the cathedral of Toledo, providing brief biographical information about Bernardino de Ribera and hence, of the manuscript, in addition to three editions of motets previously unpublished (but with several important mistakes). ${ }^{7}$ One of the great experts in the polyphony of Toledo, Michael Noone, also cited the choirbook in the voice devoted to Ribera in the Diccionario de la Música Española e Hispanoamericana, wrongly attributing the copy of the manuscript to Martín Pérez and Francisco de Buitrago, as we will show later in this article. ${ }^{8}$

In short, it seems clear to me that this manuscript, the source of a good deal of unique music composed by Bernardino de Ribera, is in need of a thorough modern study. This article thus aims to provide a detailed overview of its history, condition and a careful survey of its contents.

\section{Origins and Date}

Entirely dedicated to the Játiva-born composer, beautifully copied and decorated, the manuscript was ordered by Ribera himself in 1569. In order to commission the choirbook, Ribera had to ask for a loan of a hundred ducats, which was granted by

únicamente obras suyas. Los nombramientos que aparecen en los libros capitulares de dicha iglesia, empiezan por el de D. Cristobal Morales, posterior a Rivera. Ademas del Magnificat y dos motetes que de este autor se han publicado, hay en la misma iglesia un precioso y lujoso libro de misas. Rivera fué [sic] uno de los mejores maestros de la $1^{\mathrm{a}}$ mitad del siglo XVI, tanto en génio [sic] como en correccion; y se ve en sus obras una tendencia marcada hacia la tonalidad moderna, y una espresion notable, que lo distingue de sus antecesores.'

${ }^{5}$ Felipe Rubio Piqueras, Códices Polifónicos Toledanos (Toledo, 1925).

${ }^{6}$ Robert Stevenson, "The Toledo Manuscript Polyphonic Choirbooks and some other lost or little known Flemish Sources”, Fontes artis musicae (1973), 87-107.

${ }^{7}$ François Reynaud, La polyphonie tolédane et son milieu. Des premiers témoignages aux environs de 1600 (Brepols: Turnhout, 1996).

${ }^{8}$ Michael Noone, 'Ribera, Bernardino' in Diccionario de la Música Española e Hispanoamericana. (Madrid: Sociedad General de Autores y Editores, 1999) vol. 9, pp. 171-172. 
Governor d. Gómez Tello Girón the $4^{\text {th }}$ of May, $1569 .{ }^{9}$ Eleven months later (April $3^{\text {rd }}$, 1570), the codex was finished and the composer presented it to the cathedral chapter. The overall impression of his contemporaries must have been splendid, as shows the economical reward that Ribera received from the cathedral chapter: ${ }^{10}$ with its measures of $700 \times 400 \mathrm{~mm}$, bound in leather-covered wooden boards with metallic tacks, its hundred and fifty nine parchment folios would have to look radiant with their clear musical notation, fantastic headings and profusely decorated initials.

According to Michael Noone,${ }^{11}$ the codex was fully copied by the scribe Martín Pérez and illuminated by Francisco de Buytrago, both artisans of proven quality. ${ }^{12}$ In my opinion, this statement is debatable and extremely difficult to confirm, because the supposed copyist, Martín Pérez, died in 1558. As if the names of both artisans were unfailingly united, Buytrago is mentioned for the last time in the Libros de Obra $y$ Fábrica only a few months after the death of his colleague (January $19^{\text {th }}, 1559$ ), when he received a payment of 1500 maravedies for concluding a book of masses, possibly the Polyphonic Codex Number 9. Thus, not only we have to exclude Martín Pérez from the manuscript's authorship, but also the possible participation of Buytrago is highly doubtful.

So, who was the copyist of such enormous manuscript? I suspect that, at the moment, the question has to remain unsolved. After the Pérez and Buytrago's period (1542 - 1559), the cathedral documents mention Alonso de Morata as scribe, but usually related to more modest works, like the copy of villancicos for Christmas. In the absence of documentary evidence, we can only speculate with his probable contribution in the making of the codex.

Unfortunately, many years later some vandal deprived us of seeing the manuscript in its original state by cutting out many of the initials of the texts. Even 25 whole folios

\footnotetext{
9 Toledo cathedral, Libro de Obra y Fábrica 864 (1569), 25. 'Mandato de su sa: En quatro de mayo de 1569 años por cedula de su s ${ }^{\text {a }}$ el muy Ills Gover ${ }^{\text {or }}$ don gomez tello giron se prestaron al Racionero ber ${ }^{\text {no }}$ de Ribera Maestro de capilla cien ducados por dos años'.

10 The chapter decided to reward Ribera with two hundred ducats. Toledo cathedral, Libro de Obra y Fábrica 865 (1570), 134: "En doze de Jullio de 1570 Años di cedula por El gober[nad]or por la que dieron a ver[nardi]no de Ribera Maestro de capilla doscientos ducados en Recompensa de un libro de Musica de Canto de órgano que compuso para el serv[ici]o desta s[ant]a iglesia".

${ }^{11}$ See Michael Noone, 'Ribera, Bernardino' in Diccionario de la Música Española e Hispanoamericana. (Madrid: Sociedad General de Autores y Editores, 1999) vol. 9, pp. 171-172.

${ }^{12}$ See Juan Ruiz Jiménez, 'Creación del Canon de la Polifonía Sacra en las Instituciones Religiosas de la Corona de Castilla, 1550 - 1625' in Estudios. Tomás Luis de Victoria. Studies, in ed. Javier Suárez Pajares and Manuel del Sol (Madrid: ICCMU, Colección Música Hispana, 2013) p. 361 - 394.
} 
were torn out. Consequently, today some of the compositions that formed the original codex have been lost forever. In spite of its mutilated state, first mentioned by Rubio Piqueras in $1925,{ }^{13}$ the Polyphonic Codex Number 6 constitutes the major source of compositions created by this forgotten composer, including several unica.

A schematic state of the gatherings of Toledo Polyphonic Codex Number 6 is given below (see Table 1) in which, firstly, the torn out folios are shown: the brackets reveals the lost parts. Bold letters expresses when and where a new piece begins giving the text incipits.

Gathering 1 (f. [1] - 8)

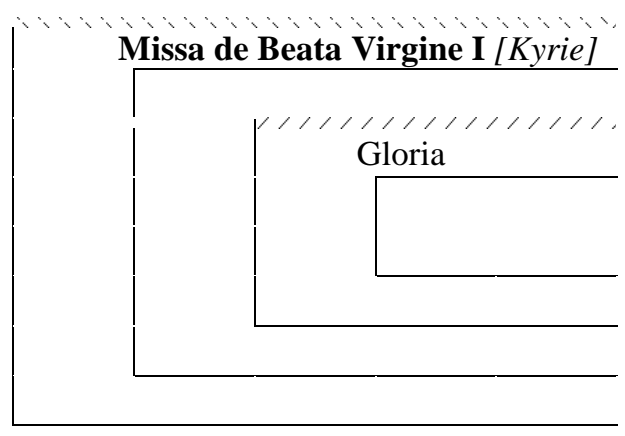

Gathering 3 (f. [17] - 24)

[Et in spiritum]

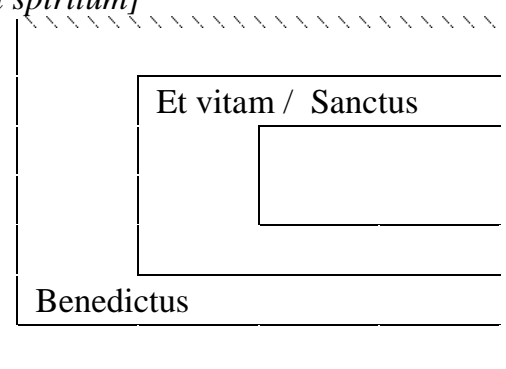

Gathering 2 (f. 9 - 16)

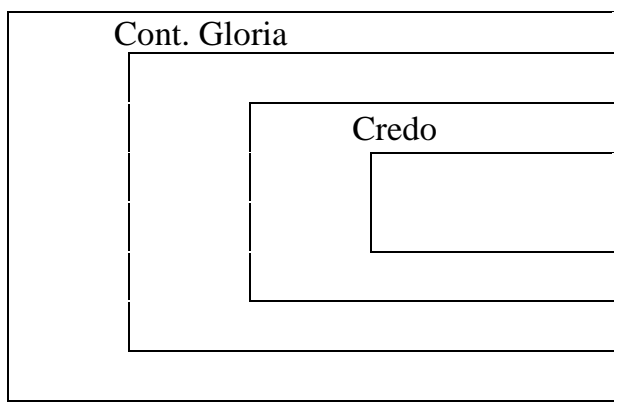

Gathering 4 (f. 25 - 32)

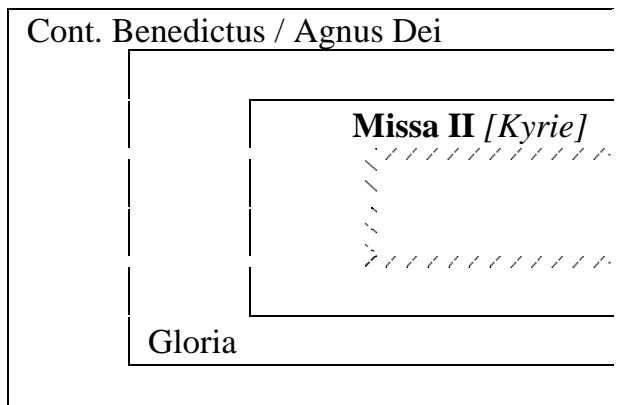

\footnotetext{
${ }^{13}$ Felipe Rubio Piqueras, Códices Polifónicos Toledanos. (Toledo, 1925) 21 - 22.
} 
Gathering 5 (f. 33 - [40])

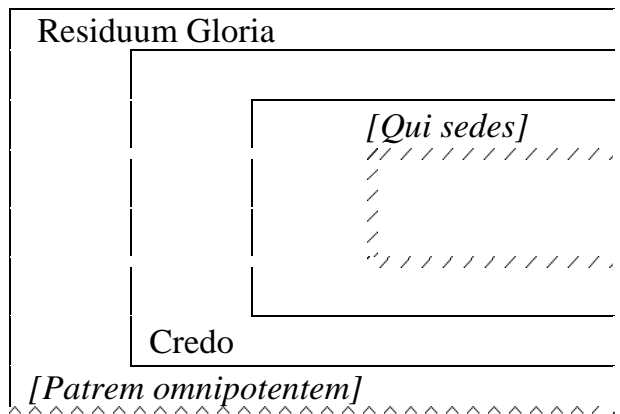

Gathering 7 (f. 49 - 56)

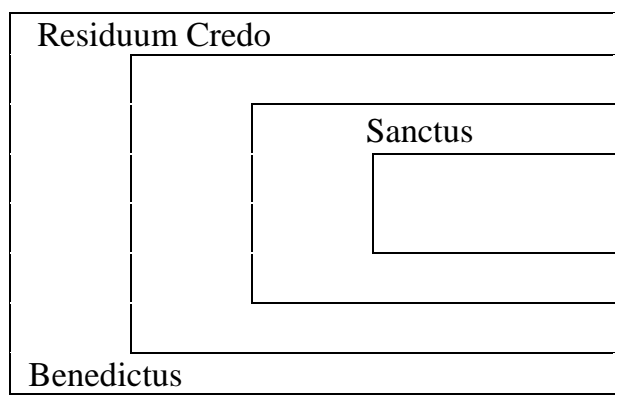

Gathering 9 (f. 65 - 72)

Cont. Ascendens Christus

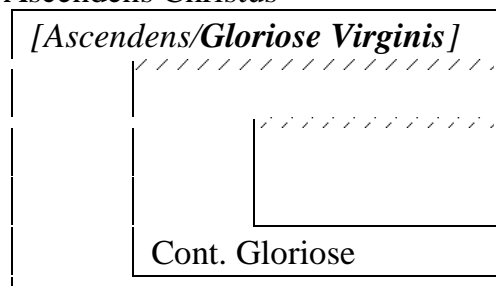

Gathering 11 (f. 81 - 90)

[Cont. o quà speciosaj]

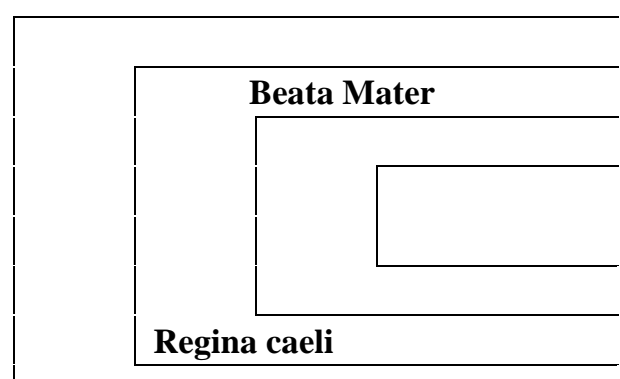

Gathering 6 (f. 41 - [48])

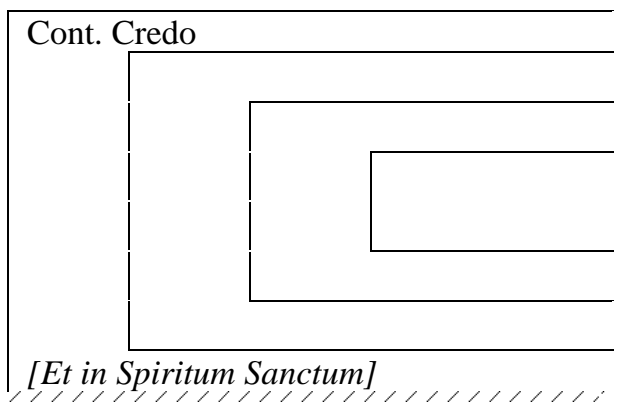

Gathering 8 (f. 57 - 64)

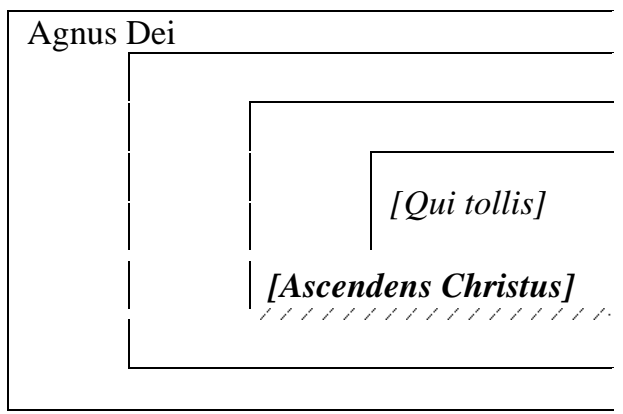

Gathering 10 (f. 73 - 80)

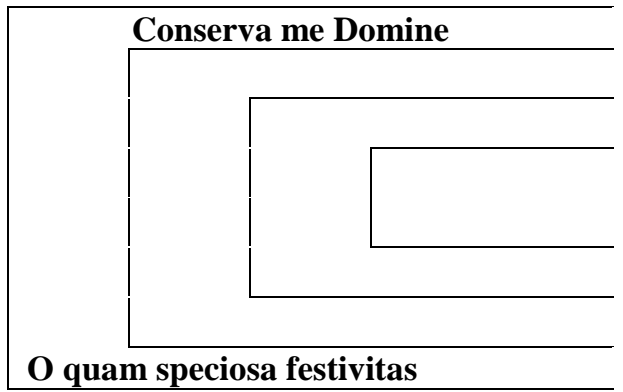

Gathering 12 (f. 91 - 98)

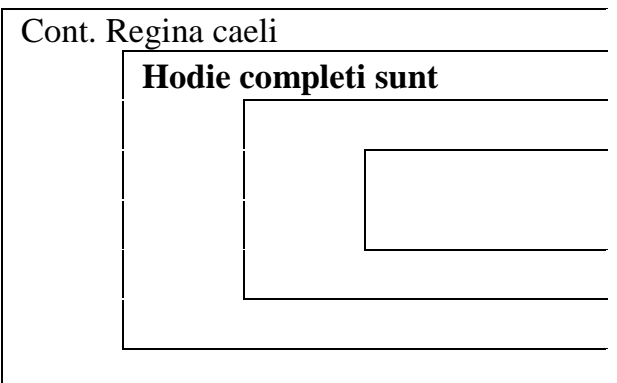


Gathering 13 (f. 99 - 106)

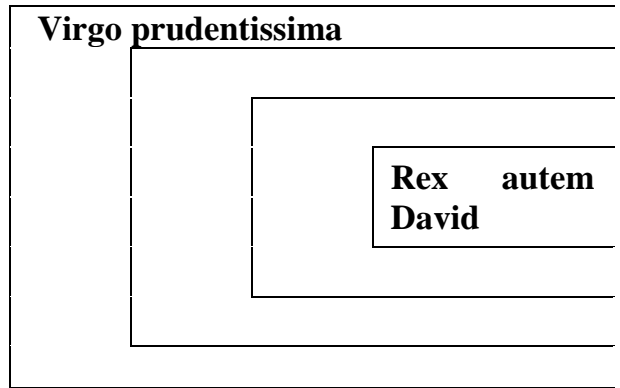

Gathering 15 (f. [115] - 122)

[Cont. Magnificat primus tonus II]

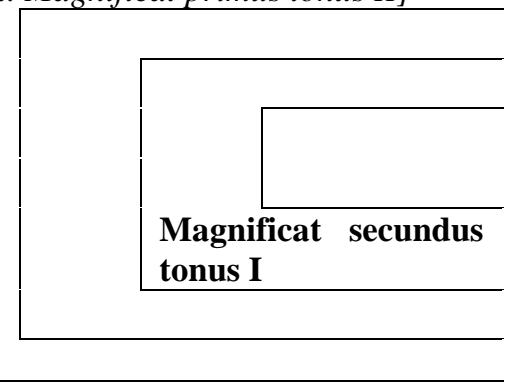

Gathering 17 (f. 131 - 138)

[Cont. Magnificat secundus tonus II]

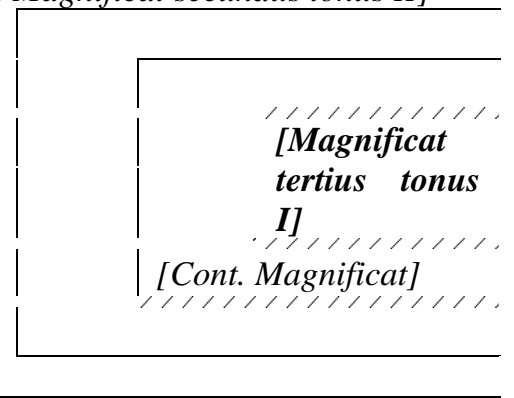

Gathering 19 (f. [147] - 154)

[Magnificat quartus tonus I]

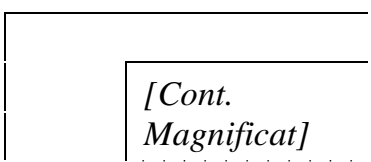

Magnificat quartus tonus II
Gathering 14 (f. 107 - 114)

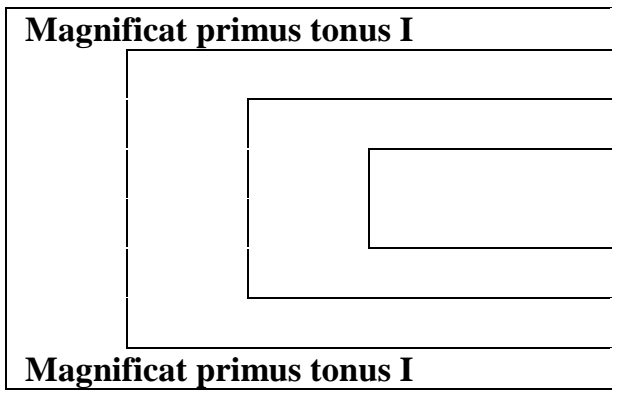

Gathering 16 (f. 123 - 130)

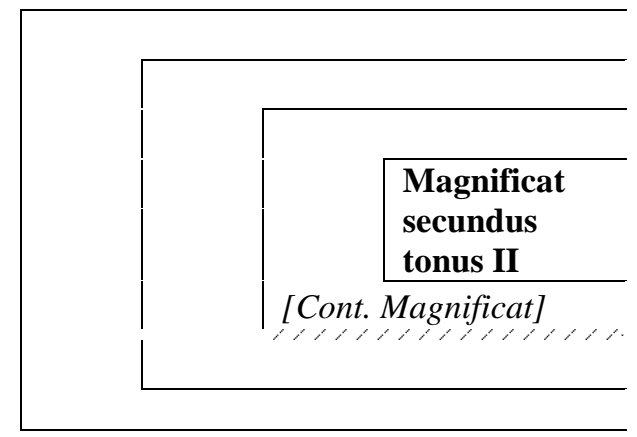

Gathering 18 (f. 139 - 146)

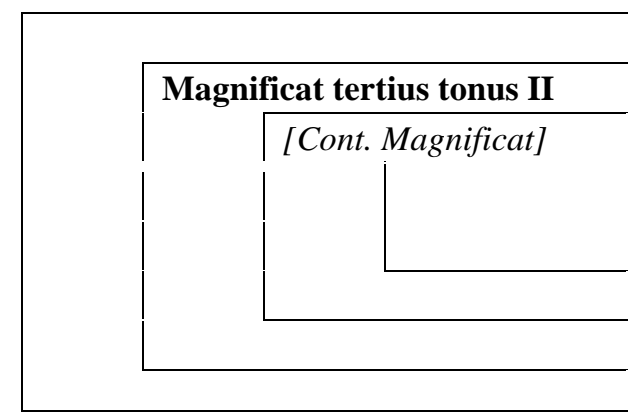

Gathering 20 (f. 155 - 160)

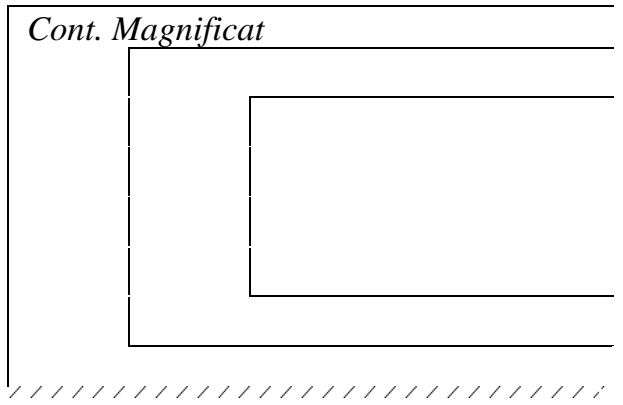

TABLE 1 - Gatherings of the Toledo Polyphonic Codex Number 6, showing the lost folios. 


\section{Contents}

The contents of the manuscript were clearly arranged in a tripartite structure. In the first part of the codex are placed two "de Beata Virgine" masses, one for four voices, the other for five. Both masses included tropes in the Gloria section (Spiritus et alme, orphanorum paraclite), and the second one uses the antiphon Ave Maria gratia plena to create a polytextual five-part Credo. Another peculiarity is presented in the Benedictus of the first mass, where is added a fifth voice, which has to be resolved by deciphering an inscription: "Cantus vnius euntis et alterius preeuntis ad finem cum breui. Retro euntisq ad principium cum semibreui cum mora in medio numerando pausas non numeratas partes". The resolution of the previous instruction is, as Robert Stevenson has shown, "begins as a Pfundnoten ostinato consisting of the breves in the cantus, sung retrograde". ${ }^{14}$ None of these masses can be fully recovered, only several sections can be transcribed.

The second part of the codex was reserved for the motets. Among the various texts choices, the antiphons clearly predominate: Beata Mater, Virgo prudentissima (for the Assumption of the Virgin, $15^{\text {th }}$ of August), Gloriosae Virginis Mariae (for the Nativity of the Virgin, $8^{\text {th }}$ of September), Hodie completi sunt (for the second vespers of Pentecost), Regina caeli and Rex autem David (Seventh Sunday after Pentecost). Conserva me, Domine, a setting based on the psalm 16, and Ascendens Christus in altum is a matins responsory for the Ascension. In addition, the manuscript contains a motet composed for a special event: the six-voiced $O$ quam speciosa festivitas was created by Ribera to celebrate the transfer of the relics of Saint Eugenius from France to Spain in 1565.

The third and final section of the codex includes eight Magnificats, two to each of the first four tones (odd and even verses). It seems reasonable to think that these eight compositions are only the first half of a collection of sixteen Magnificats, covering in such way all the spectrum of tones. But, at least the moment, we don't know if Ribera composed the rest of the collection.

A list of the works of Toledo Polyphonic Codex Number 6 is given below (see Table 2) in which, firstly, the foliation is shown: the brackets reveals the lost folios.

\footnotetext{
${ }^{14}$ Robert Stevenson, 'The Toledo Manuscript Polyphonic Choirbooks and some other lost or little known Flemish Sources', Fontes artis musicae (1973), 103.
} 
Next, the table gives the text incipits and the number of voices of each composition, followed by the concordances.

\begin{tabular}{|c|c|c|c|}
\hline Folios & Text Incipit & Voices & Concordances \\
\hline$[1]-\left[28^{\mathrm{r}}\right]$ & Missa "de Beata Virgine" & 4 & unicum \\
\hline$\left[28^{\mathrm{v}}\right]-[61]$ & Missa "de Beata Virgine" & 5 & unicum \\
\hline$[62]-\left[67^{\mathrm{r}}\right]$ & Ascendens Christus in altum & 8 & unicum \\
\hline$\left[67^{\mathrm{v}}\right]-74^{\mathrm{r}}$ & Gloriose Virginis Marie & 5 & unicum \\
\hline $74^{\mathrm{v}}-80^{\mathrm{r}}$ & Conserva me, Domine & 6 & unicum \\
\hline $80^{\mathrm{v}}-84^{\mathrm{r}}$ & O quam speciosa festivitas & 6 & unicum \\
\hline $84^{\mathrm{v}}-87^{\mathrm{r}}$ & Beata Mater & 6 & unicum \\
\hline $87^{\mathrm{v}}$ & Domine quando veneris & & Not by Ribera \\
\hline$\left[88^{\mathrm{r}}\right]-92^{\mathrm{r}}$ & Regina caeli & 5 & unicum \\
\hline $92^{\mathrm{v}}-98^{\mathrm{v}}$ & Hodie completi sunt & 5 & unicum \\
\hline $98^{\mathrm{v}}-103^{\mathrm{r}}$ & Virgo prudentissima & 6 & E-VAcp 20 \\
\hline $103^{\mathrm{v}}-107^{\mathrm{r}}$ & Rex autem David & 5 & E-Vacp 20 \\
\hline $107^{\mathrm{v}}-114^{\mathrm{r}}$ & Magnificat primus tonus & 4 & E-VAc, Leg $1 / 24$ \\
\hline $114^{\mathrm{v}}-120^{\mathrm{r}}$ & Magnificat primus tonus & 4 & unicum \\
\hline $120^{\mathrm{v}}-127^{\mathrm{r}}$ & Magnificat secundus tonus & 4 & unicum \\
\hline $127^{\mathrm{v}}-[134]$ & Magnificat secundus tonus & 4 & unicum \\
\hline$[135]-141^{\mathrm{r}}$ & Magnificat tertius tonus & 4 & unicum \\
\hline $141^{\mathrm{v}}-[147]$ & Magnificat tertius tonus & 4 & unicum \\
\hline$[148]-153^{\mathrm{r}}$ & Magnificat quartus tonus & 4 & E-Gu \\
\hline $153^{\mathrm{v}}-159^{\mathrm{r}}$ & Magnificat quartus tonus & 4 & unicum \\
\hline
\end{tabular}

TABLE 2 Foliation, text incipit, number of voices and concordances of the Polyphonic Codex N. 6 of Toledo cathedral.

As we can see, there is clearly a bias towards Marian works: the two Masses are both dedicated to the Virgin Mary, and many of the motets are on Marian texts. But how do these contents fit in with the liturgical practice of the cathedral? We have to take into 
account that, in 1568 and 1570 respectively (exactly at the time when the manuscript was being copied), Pope Pius V promulgated a new Breviary and Mass liturgy, reflecting the reforms of the Council of Trent. Although the musical consequences of the Council have been overestimated and the adoption of the new Tridentine Mass liturgy came into use in Toledo in 1576, as early as 1565 the provincial council of Toledo documented his position on the understanding of text:

Bishops also care that the modulation of voice does not make unintelligible the words from the Psalms and other often sung, darkening at the same time their sense with the din that moves. So they kept the so-called canto de órgano so they can understand the words that are said and focus more on the pronunciation. ${ }^{15}$

The previous passage makes clear the fundamental relevance of textual understanding, but it has nothing to do with composition, but with interpretation. Nonetheless, some characteristic features of the music by Ribera, such as the densely imitative textures, his ever-changing musical motives, and the troped masses that open the choirbook seems not to fit so well with the post-tridentine preferences. In this sense, his music seems to me highly influenced by Morales and the mid-century Flemish composers, like Gombert or Champion (authors whose works are largely preserved in Toledo, as Stevenson and many others have shown). But, on the other hand, such "horizontal" conception is carefully mixed with triadic, homophonic passages and a marked preoccupation for textual expression that helps to achieve a balance in his compositions that points out to the next generation. So, it is not strange that, many years after the implementation of the conciliar reforms, the cathedral chapel still continued to perform compositions by Ribera, as shown the next extract from the Ceremonial de Juan Chaves Arcayos:

$\ldots$ and we note that this day, having sung the sanctus, the singers say [sing] from the lectern of the eagle stands a motet which is the Benedictus antiphon of this Sunday, Cum

\footnotetext{
15 The complete quotation, extracted from Concilio provincial de Toledo, 1565-66, Sesión II, dec. XXI, read as follows: 'Cuiden también los obispos de que la modulación de voz no haga ininteligibles las palabras de los salmos y de lo demás que suele cantarse, oscureciendo al propio tiempo su sentido con el estrépito que se mueve. Por tanto, conservarán el canto llamado "de órgano" de modo que puedan entenderse las palabras que se dicen y fijarse más en la pronunciación que en las canturías curiosas. También tendrán un extremo cuidado de que la música que se emplea en alabanzas divinas no imite los tonos profanos del teatro, del amor impúdico o de la guerra.'
} 
sublevasset oculos for 7 voices, a work composed en puncto de organo by Bernardino de Ribera, racionero and choirmaster of this holy church of Toledo. ${ }^{16}$

Another controversial matter is to speculate on how these compositions were performed. The Table 3 shows, as an example, the members of the cathedral chapel at the time of the arrival of Bernardino de Ribera. As we can see, it was a large number of forces and, taken into account that Toledo cathedral was at this time the Spain's leading ecclesiastical institution, and the efforts to contract the best musicians from all over the country, we can be sure of the high quality of the musicians.

The presence of nine ministriles is remarkable. But, as François Reynaud has demonstrated, to know when the musicians performed is not as easy as verifying their presence at the cathedral. Even the documents which have helped us before, like the Ceremonial de Juan Chaves Arcayos or the Memorial of 1604, serve only to substantiate the immense diversity of ways in which singers and instruments joined in musical performances.

\begin{tabular}{|c|c|c|c|}
\hline Name & Status & Position & Salary (mrs) \\
\hline Bernardino de Ribera & Racionero & Choirmaster & 30.000 \\
\hline Bartolome de Quevedo & Racionero & Ex-Choirmaster/Singer (Tenor) & 30.000 \\
\hline Lucas Sanchez & Racionero & Singer (Tiple) & 60.000 \\
\hline Hernando de Lerma & Racionero & Singer (Contralto) & 40.000 \\
\hline Gonzalo Mexia & Racionero & Singer (Contrabajo) & 37.500 \\
\hline Juan Ortiz & Racionero & Singer (Contratenor) & 35.000 \\
\hline Juan de Aguilera & Racionero & Singer (Tenor) & 32.500 \\
\hline Alonso de Salas & Racionero & Singer (¿?) & 7.500 \\
\hline Alonso Nieto & Racionero & Singer (¿?) & 6.000 \\
\hline Juan de Peñalosa & Racionero & Keyboard Musician & 45.000 \\
\hline Francisco Lopez & Racionero & Keyboard Musician & 35.000 \\
\hline Alonso Ortiz & Salaried & Singer & 66.000 \\
\hline Alonso Maldonado & Salaried & Singer & 35.000 \\
\hline Alonso Carvajal & Salaried & Singer & 50.000 \\
\hline Sebastian Perez & Salaried & Singer & 40.000 \\
\hline Gonzalo Martinez & Salaried & Singer & 34.000 \\
\hline Juan de Aranda & Salaried & Singer & 25.000 \\
\hline Alonso de Guevara & Salaried & Singer & 23.000 \\
\hline Juan Cortes & Salaried & Singer & 23.000 \\
\hline
\end{tabular}

16 The mentioned motet, not among the works of the Codex, is now lost. Ceremonial de Juan Chaves Arcayos, f. 493v: ' . . y se note que este día mientras los sanctus después de haverlos cantado dicen los cantores al facistor de las gradas del águila un motete que es la $a^{\mathrm{a}}{ }^{\mathrm{a}}$ del benedictus desta dominca cum sublevasset oculos a 7 voces la qual compuso en puncto de órgano Bernardino de Ribera, racionero y maestro de capilla desta sancta yglesia de Toledo.' 


\begin{tabular}{|c|c|c|c|}
\hline Pedro Ortiz & Salaried & Singer & 18.000 \\
\hline Diego de Leon & Salaried & Singer & 15.000 \\
\hline Luis de Villegas & Salaried & Singer & 10.000 \\
\hline Andres de Ávila & Salaried & Singer (psalmear) & 15.000 \\
\hline Pedro de Tamayo & Salaried & Singer (psalmear) & 12.000 \\
\hline Hysidro Rodriguez & Salaried & Singer (psalmear) & 15.000 \\
\hline Francisco Rodriguez & Salaried & Singer (psalmear) & 5.000 \\
\hline Raphael Mexia & Salaried & Singer & 25.000 \\
\hline Sanchez & Salaried & Singer & 25.000 \\
\hline Bartolomé Martinez & Salaried & Singer & 20.000 \\
\hline Hyeronimo Lopez & - & Ministril (flute / shawm) & 25.000 \\
\hline Nicolas de Figueroa & - & Ministril (shawm) & 35.000 \\
\hline Juan Peraza "el mozo" & - & Ministril (shawm / cornet) & 82.500 \\
\hline Gaspar Maynete & - & Ministril (shawm tiple) & 64.750 \\
\hline Thomas Lopez & - & Ministril (shawm altus) & 40.000 \\
\hline Antonio de Sant Pedro & - & Ministril (shawm tenor) & 39.000 \\
\hline Juan de Cordoba & - & Ministril (sackbutt) & 39.000 \\
\hline Garci Gonzalez & - & Ministril (bass sackbutt) & 50.000 \\
\hline Juan del Castillo & - & Ministril (;?) & 35.000 \\
\hline Juan Ortiz & Racionero & Musician to perform choros & 6.000 \\
\hline Juan Gomez & - & Musician to perform choros & 6.000 \\
\hline Juan de Benavente & - & Musician to perform choros & 6.000 \\
\hline Luis de Villegas & - & Musician to perform choros & 6.000 \\
\hline
\end{tabular}

TABLE 3 Members of the chapel of the cathedral of Toledo, year 1563.

On another level, we have to take into account that the motet is an extremely flexible genre. Undoubtedly, Bernardino de Ribera composed his motets responding to the needs of Toledo cathedral, surely receptive to the spiritual and religious changes which were producing at the time. But we have to think on the motet as a versatile genre appropriate to realize different functions in a wide range of contexts. ${ }^{17}$ The assumption that the motet necessarily functioned within the liturgical context prescribed by its text, as David Crook has recently said, "proved untenable in the face of references to specific performances". ${ }^{18}$

To sum up, the Toledo Polyphonic Codex $N^{o} 6$ seems to me a compositional résumé of the contributions made by Bernardino de Ribera along his seven years as choirmaster at Toledo, principally in the field of the devotion to the Virgin Mary. By doing so, he was trying to establish himself at the same level of previous choirmasters,

\footnotetext{
${ }^{17}$ Even Masses could have been more versatile than we have thought, as shown by Honey Meconi, 'Listening to Sacred Polyphony', Early Music 26 (1998), 374-379.

${ }^{18}$ David Crook, 'The exegetical motet', The Journal of the American Musicological Association 68/2 (2015), 255-316.
} 
like Cristóbal de Morales: if we examined carefully the musical manuscripts preserved in Toledo cathedral, we observe a great amount of Marian compositions, among which stand the Missa "de Beata Virgine" by Morales (preserved in two different manuscript codices, 27 and 29), and the famous Magnificat settings by the same composer. The relationship between the creations by Morales and Ribera could provide us, in the near future (I hope), interesting results.

\section{Conclusions}

The choirbook was completed during Ribera's last year at Toledo. After eight years of service at Toledo cathedral, Ribera received a letter from the chapter of Murcia cathedral, in which he was offered the post of maestro. ${ }^{19}$ It was an offer he could hardly refuse. On one hand, the emotional ties that bound Bernardino de Ribera with the city of Murcia were very powerful because, accompanying his father, the young Ribera had spent part of his adolescence in it. ${ }^{20}$ On the other hand, the economical conditions were more than succulent: two hundred ducats were a considerable amount of money, plus 24 bushels of wheat, 40 gallons of wine and, of course, a house.

By giving a kind of summary of his compositions to the cathedral, presented in the form of such huge choirbook, it seems clear that Ribera would not abandon Toledo without leaving their mark in the cathedral. The impressive codex was, undoubtedly, the best legacy he could leave. But, at this point, we could ask ourselves several questions. On one hand, although some scholars like François Reynaud believe that the codex is integrally formed by works created for the cathedral of Toledo, the truth is that, except for $O$ quam speciosa festivitas (motet composed, as I noted above, for a special occasion) there are no solid arguments to demonstrate such conjecture.

In fact, the inclusion of well-known tropes in both masses "de Beata Virgine" could lead us to think that these pieces were composed in a previous period. As we all know, the use of tropes were "banned" in the Council of Trent, always searching for a

\footnotetext{
${ }^{19}$ Murcia cathedral, Actas Capitulares, Book 6 (1570 - February, 12 $\left.12^{\text {th }} 1572\right)$, Friday, $22^{\text {nd }}$ of September, 1570, f. $8^{v}$. "Este dia secretario en Cab[ildo] como el señor licen[ciado] Arias Gallego de parte del señor obispo abia dixo que se ofrezca a bernar[di]no de Ribera maestro de capilla y R[acioner]o de toledo de venir a salario a esta santa yg[lesia] de maestro de capilla le daran doszientos ducados en dineros de salario y mas la casa en que suelen vivir los maestros de capilla y el trigo y vino que se le acostumbra dar en el granero".

${ }^{20}$ Bernardino's father, Pedro de Ribera, was maestro de capilla of Murcia cathedral during almost thirty years $(1535-1565)$.
} 
better textual comprehension. The Council concluded in 1563, practically coinciding with the arrival of Ribera at the cathedral of Toledo. However, we have to remember that the new Missal and Breviary of Pius V were not published until 1568 and 1570 respectively, that is to say, at the time when Ribera commissioned and delivered his manuscript to the Toledo temple. Obviously, is a fallacy to think that a concrete historical fact produced in a given place, however relevant it might be, changes everything ipso facto. Everything has to take a process of implementation and adaptation. Toledo adopted the new liturgy in 1570, so Ribera was not doing anything anachronistic, and the appearance of tropes or polytextual compositions might be a perfectly normal procedure at his time.

On the other hand, what becomes clear is the high appreciation enjoyed by Ribera at his time. The gratification received for the codex, in addition to the constant rewards given by the chapters of the diverse ecclesiastical institutions in which he has worked, and the different salary increases at Toledo seems to confirm his high status. Furthermore, as the Ceremonial de Juan Chaves Arcayos shows, the repertoire created by Ribera continued performed at Toledo many years after the Council. Not only that, but his compositions were copied in manuscripts during the seventeenth and even eighteenth centuries. Therefore, it seems that his music was much esteemed during a long time, so it is clear that his figure deserves more consideration. Surely, further analysis (perhaps a more accurate understanding of his compositional processes may lead us to reconstruct the damaged compositions) and research about his life and music could bring us some valuable information about broader aspects of musical and cultural atmosphere in sixteenth century Spain. 